\title{
Internalisasi Nilai-Nilai Karakter Religius Siswa di Madrasah Ibtidaiyyah Nurussalam Mantingan
}

\author{
Rini Setyaningsih ${ }^{1}$, Siti Nikmatul Rochma ${ }^{2}$ \\ ${ }^{1}$ Program Studi Manajemen Pendidikan Islam, UIN Sultan Syarif Kasim Riau \\ ${ }^{2}$ Program Studi Pendidikan Bahasa Arab, Universitas Darussalam Gontor \\ e-mail: rini.setyaningsib@uin-suska.ac.id
}

\begin{abstract}
This study aims to determine the madrasah strategy in internalizing the values of religious character to students. The type of research the writer uses is descriptive qualitative research, with data collection techniques using in-depth interviews, documentation and participatory observation. Data analysis techniques in this study used data reduction, data presentation and data verification. The internalization stage or inculcation of religious character values for classes 1-2 MI Nurussalam is at the value transformation stage, classes 2 (process) and 3 are at the value transaction stage, while classes 4,5 and $6 \mathrm{MI}$ are at the value transinternalization stage. MI Nurussalam's strategy in internalizing the values of religious character is divided into two fields, namely the academic and nonacademic fields. The strategy in the academic field of MI Nuruusalam is to develop the Madrasah curriculum from grade 1 to grade 6 by adding special Islamic subjects and fostering a love affair with Arabic (the key to opening Islamic insights). In the non-academic field, MI Nurussalam integrates religious character values into routine activities, spontaneous activities, exemplary activities, and the Madrasah environmental conditioning system.
\end{abstract}

Keywords: Internalization of values, religious and academic character

\section{PENDAHULUAN}

Pendidikan merupakan sebuah subsistem yang sekaligus juga merupakan suatu sistem yang kompleks dalam kehidupan. Pertama, sebagai sebuah subsistem, pendidikan merupakan salah satu aspek kehidupan yang berjalan dengan dipengaruhi oleh berbagai aspek eksternal yang saling terkait seperti aspek politik, ekonomi, sosial-budaya, pertahanan keamanan dan ideologi yang mempengaruhi penyelenggaraan suatu pendidikan. Kedua, pendidikan sebagai suatu sistem menunjukkan bahwa pendidikan terdiri dari berbagai perangkat yang saling mempengaruhi secara internal sehingga dalam rangkaian proses pendidikan, berbagai perangkat atau unsur di dalamnya perlu mendapat jaminan mutu yang layak dari berbagai stakeholder terkait, dan tentu saja peran manajemen sangat berpengaruh terhadap keberhasilan setiap lembaga pendidikan dalam mencapai tujuan. 
Menurut Hasbullah (2010:147), Pendidikan Islam menjadi salah satu isu penting dalam pembahasan yang menyangkut kehidupan umat Islam. Apabila ditinjau dari sejarahnya, selama sekian abad pendidikan Islam merupakan satu-satunya lembaga pendidikan yang ada di Indonesia, sebelum penjajah Belanda memperkenalkan sistem pendidikan modern di abad 19. Lembaga-lembaga pendidikan seperti surau, majlis taklim, pesantren dan madrasah sudah diterima dan memiliki basisnya sendiri yang sangat kuat dalam kehidupan bangsa Indonesia.

Kehadiran undang-undang otonomi daerah telah membawa sejumlah perubahan, bukan hanya dalam bidang pemerintahan dan birokrasi, namun terutama dengan diserahkannya sejumlah kewenangan kepada daerah, salah satunya dalam bidang pendidikan. Kewenangan tersebut menuntut adanya perubahan berupa pembaruan sistem pendidikan yang sekian lama dikelola secara sentralistik oleh pemerintah pusat dengan menafikan keragaman, perbedaan, kultur, agama, dan sebagainya yang menyebabkan terpuruknya kualitas pendidikan di Indonesia.

Banyak orang beranggapan bahwa pelaksanaan otonomi daerah memberikan harapan akan perbaikan penyelenggaraan pendidikan yang akan meningkatkan kualitas output-nya. Namun, ternyata harapan itu menghadapi berbagai tantangan. Salah satunya adalah pemegang kebijakan yang pola pikirnya masih sangat prosedural, serba juklak, juknis sehingga menghambat lahirnya kreativitas, motiavasi, dan upaya-upaya inovatif.

Madrasah sebagai salah satu lembaga pendidikan Islam yang merupakan subsistem pendidikan nasional ini pun tidak terlepas dari kebijakan otonomi daerah. Madrasah Ibtidaiyyah adalah jenjang Madrasah yang paling dasar untuk menanamkan nilai-nilai keislaman pada siswa-siswanya. Namun yang menjadi soalan saat ini, sudah mampukah Madrasah Ibtidaiyyah dalam menanamkan nilai-nilai keislaman atau nilai religius kepada para muridnya?.

MI Nurussalam adalah MI swasta yang memiliki jumlah siswa terbanyak di kecamatan Mantingan. Seluruh tenaga pengajar di MI Nurussalam memiliki latar belakang yang notabenenya alumni pesantren. Untuk itu penulis tertarik untuk mengangkat judul "Internalisasi Nilai-nilai Karakter Religius Siswa di Madrasah Ibtidaiyyah Nurussalam Mantingan".

\section{METODOLOGI}

Penelitian ini adalah penelitian dengan pendekatan kualitatif, yaitu jenis penelitian yang temuan kajiannya tidak didapatkan melalui teknik analisis statistik atau bentuk hitungan lain.Teknik pengumpulan data yang penulis gunakan adalah teknik Wawancara mendalam, dokumentasi, dan observasi. Wawancara mendalam penulis lakukan dengan beberapa narasumber yang penulis anggap mampu memberikan data yang penulis lakukan. Informan kunci dalam wawancara ini adalah kepala madrasah dan wali kelas 1 sampai kelas 6, sedang informan pendukungnya adalah guru-guru mata pelajaran di setiap kelas. Data kegiatan siswa di MI Nurussalam ini banyak penulis dapatkan dari dokumentasi baik berupa foto kegiatan ataupun kurikulum pembelajaran di MI Nurussalam. Penulis juga mengumpulkan data dengan observasi partisipatif di lapangan untuk melihat dengan jelas beberapa kegiatan guru untuk menginternalisasikan nilai-nilai karakter keislaman atau nilai-nilai karakter religius kepada para siswa. 
Teknik Analisa datamenggunakan model Miles dan Hubermen (2014), data yang diperoleh kemudian dianalisis melalui langkah-langkah berikut: 1. Reduksi data, yakni proses penggabungan dan penyeragaman data yang diperoleh menjadi satu bentuk tulisan yang akan dianalisis; 2. Display data atau penyajian data, yakni dapat dilakukan dalam bentuk uraian singkat, bagan, atau hubungan antar kategori. Dalam hal ini penulis menggunakan uraian singkat yang bersifat naratif tentang bentuk internalisasi nilai-nilai religius yang diberikan oleh guru kepada siswanya; 3.Kesimpulan atau verifikasi data, yakni penulis mengambil kesimpulan berdasarkan data yang ditelaah dan diuji keabsahannya.

\section{HASIL PENELITIAN}

Proses internalisasi atau penanaman nilai-nilai religius kepada siswa di madrasah tidaklah mudah. Secara harfiah kata internalisasi diartikan sebagai penghayatan, pendalaman, penguasaan secara mendalam yang berlangsung melalui binaan, bimbingan, dan sebagainya sehingga nilai-nilai yang didapatkan dari proses internalisasi akan lebih mendalam dan tertanam dalam diri seseorang. (Bagja Waluyo, 2007:43)

Internalisasi nilai dalam karya Rahmat Mulyana didefinisikan sebagai menyatunya nilai dalam diri seseorang atau dalam bahasa psikologi merupakan penyesuaian keyakinan, nilai, sikap, perilaku, praktik, dan aturan baku pada diri seseorang.(Rahmat Mulyana, 2004:21). Menurut Chabib Thoha, internalisasi nilai yakni teknik dalam pendidikan nilai yang sasarannya adalah sampai pada pemilikan nilai yang menyatu dalam kepribadian peserta didik.(Chabib Thoha, 1996:87-93).

Menurut Muhaimin, proses internalisasi yang dikaitkan dengan siswa atau anak asuh ada tiga tahapan yaitu: 1. Tahap transformasi nilai, yakni proses yang dilakukan oleh pendidik dalam menginformasikan nilai-nilai yang baik dan kurang baik. Pada tahap ini hanya terjadi komunikasi verbal antara pendidik dan siswa atau anak asuh; 2. Tahap transaksi nilai, yaitu pendidikan nilai dengan jalan melakukan komunikasi dua arah, atau interaksi antara siswa dengan pendidik yang bersifat interaktif timbal balik; 3. Tahap transinternalisasi, tahap ini jauh lebih mendalam dati tahapan yang lain. Yakni bukan hanya dilakukan dengan komunikasi verbal tapi juga mental dan kepribadian.

Jadi, internalisasi nilai-nilai religius pada siswa MI adalah teknik pembinaan yang dilakukan melalui proses yang mendalam dan menghayati yang dipadukan dengan nilai pendidikan secara menyeluruh dengan capaian standar yakni menyatunya nilai-nilai yang ditanamkan dengan kepribadian siswa MI sehingga menjadi satu karakter khusu dalam diri siswa tersebut.

Noeng Muhajir dalam Chabib Thoha (1996: 77-79), mengemukakan strategi penanaman nilai-nilai pendidikan yaitu, tradisional, bebas, reflektif dan transinternal. Strategi tradisional adalah dengan jalan memberikan nasihat atau indoktrinasi. Yaitu memberitahukan secara langsung nilai-nilai mana yang baik dan kurang baik. Kelemahan dalam hal ini adalah siswa sekedar tahu atau hafal jenis-jenis nilai tertentu yang baik dan kurang baik, tapi belum tentu melaksanakannya. Strategi bebas, yakni kebalikan strategi tradisional. Jadi guru tidak memberitahukan kepada siswa nilai-nilai yang baik dan buruk, pembentukan nilai secara bebas dengan memberikan kebebasan sepenuhnya kepada siswa untuk memilih dana menemukan nilai yang diambilnya. Kelemahannya siswa belum tentu mampu dalam memilih nilai dan masih perlu bimbingan dari guru/pendidik. Strategi reflektif yakni guru dan siswa sama-sama terlibat aktif. Dalam hal ini mendidik siswa 
dengan jalan mondar mandir antara menggunakan pendekatan teoritik ke empiric, atau dengan pendekatan deduktif ke induktif atau bahkan sebaliknya.

Strategi transinternal, yaitu mengajarkan nilai dengan jalan melakukan tahapan internalisasi nilai berupa transformasi nilai, dilanjutkan dengan transaksi nilai hingga transinternalisasi nilai. Dalam strategi ini guru dan siswa sama-sama terlibat dalam proses komunikasi verbal dan komunikasi fisik serta adanya keterlibatan komunikasi batin antar guru dengan siswanya. Guru berperan sebagai penyaji informasi, pemberi contoh dan teladan serta sebagai sumber nilai yang melekat dalam pribadinya sedangkan siswa menerima informasi dan merespon terhadap stimulus guru secara fisik dan biologis serta memindahkan dan mempolakan pribadinya untuk menerima nilai-nilai kebenaran sesuai dengan kepribadian guru tersebut.

Berdasarkan landasan teori yang penulis dapatkan serta data lapangan yang sudah penulis peroleh selama ini, maka dapat penulis kategorikan bahwa proses internalisasi nilainilai religius yang ada di MI Nurussalam untuk kelas 1-2 MI berada pada tahap transformasi nilai, yakni guru-guru di MI Nurussalam memberikan informasi kepada siswa kelas 1 MI tentang nilai-nilai religius seperti Iman kepada Allah itu wajib, menjalankan sholat puasa itu wajib, sebelum dan sesudah makan harus berdoa, berbohong itu dosa, dan lain sebagainya. Dalam hal ini siswa kelas 1 dan 2 masih pada tahapan mengetahui nilainilai tersebut dan belum dapat menghayati serta melaksanakannya secara kosisten di setiap harinya, dan khusus untuk siswa kelas 2 disamping transformasi nilai, guru telah memulai tingkatan internalisasi selanjutnya sedikit demi sedikit.

Tahapan internalisasi nilai-nilai religius untuk kelas 2 dan 3 MI berada pada tahapan transaksi nilai. Dengan bukti di lapangan guru dengan siswa melakukan komunikasi dua arah, atau interaksi antara siswa dengan guru yang bersifat interaktif timbal balik dalam hal penanaman nilai-nilai religius. Seperti contoh dalam hal ini adalah, guru mengajak siswa sebelum makan dan minum untuk berdoa dan siswa pun dapat mengikutinya dengan baik. Tahapan internalisasi nilai-nilai religius untuk kelas 4, 5 dan 6 MI berada pada tahapan trans-internalisasi, tahap ini jauh lebih mendalam dari dua tahapan yang lain. Yakni bukan hanya dilakukan dengan komunikasi verbal guru dengan murid tapi juga mental dan kepribadian. Seperti contoh dalam hal ini, siswa kelas 4, 5, dan 6 di MI Nurussalam sudah dapat melaksanakan ibadah sholat sunnah dhuha di MI tanpa di suruh. Dengan keyakinan nilai-nilai yang mereka dapatkan dari kelas 1-3 mereka terapkan dengan baik ketika mereka kelas 4, 5 dan 6.

Dalam hal keyakinan nilai dan pelaksanaan di kehidupan siswa setiap harinya tidak lepas dari proses-proses pendekatan yang dilakukan oleh seluruh wali kelas dan guru mata pelajaran di masing-masing kelas. Strategi dan kebijakan Kepala Madrasah dalam hal internalisasi nilai-nilai religius di MI Nurussalam juga sangat mendukung. Untuk itu penulis akan menjabarkan beberapa poin penting strategi internalisasi nilai-nilai religius MI Nurussalam kepada seluruh siswa.

\section{Bidang Akademik}

Pada bagian akademik, MI Nurussalam mempunyai desain pengembangan kurikulum yang berbeda dengan MI swasta lain di Kecamatan Mantingan. Dalam menginternalisasikan nilai-nilai religius, semenjak kelas 1 dan 2 para siswa diwajibkan untuk mengikuti mata pelajaran keislaman seperti kurikulum MI lainnya seperti Akidah Akhlah, Al-Qur'an Hadis, Bahasa Arab, Fiqih, dan lain sebagianya. Namum yang menarik di MI 
Nurussalam ini, selain mata pelajaran yang disebutkan tadi, penulis menemukan mata pelajaran wajib untuk kelas 1 dan 2 yang belum ada di MI lainnya adalah mata pelajaran: Al-Qur'an/Iqra', Hafalan Doa dan Surat Pendek, serta imla', dengan pelajaran-pelajaran inilah semenjak kelas 1 dan 2 MI sudah diajarkan mengenal bahkan hafal dan dapat menulis dengan lancar huruf-huruf hijaiyyah untuk membekali mereka membaca al-Qur'an dengan Fasih pada tingkat selanjutnya.

Pada tingkatan kelas 3 sampai dengan kelas 6, mata pelajaran untuk menginternalisasikan nilai-nilai religius yang berbeda dengan MI lain yakni, mata pelajaran al-Mahfudzat. Dimana mata pelajaran ini berisikan kata-kata mutiara, atau motivasi kepada diri siswa agar lebih memaknai nilai-nilai religius dan dapat di implementasikan pada kehidupan sehari-hari baik di Madrasah mapaun di rumah. Untuk evaluasi pembelajaran kelas 3 sampai dengan kelas 6, MI Nurussalam selalu menggunakan teknik evaluasi Tulis dan Lisan. Untuk evaluasi pembelajaran secara lisan, MI Nurussalam menggunakan nama Ujian Lisan Ibadah Qouliyah dan Ibadah Amaliyah. Dalam ujian lisan ini, para siswa diminta untuk memasuki ruang ujian satu persatu dan guru meminta mereka untuk mempraktekkan sejumlah ibadah (sholat, wudhu, tayamum, azan, iqomah, dll) dengan bacaan/doa yang fasih serta meminta mereka untuk mengahafalkan surat-surat pendek serta doa harian.

Dan yang membuat penulis tertarik lagi, bahwa untuk kelas 6 yang akan menghadapi Ujian Nasional (UN) atau Ujian Akhir Madrasah Berstandar Nasional (UAMBN) wajib mengikuti karantina selama kurang lebih 2-3 bulan. Dalam karantina ini siswa kelas 6 selain dibimbing dalam hal persiapan UN dan UAMBM, mereka juga dibekali ceramah dan praktik religius setiap harinya. Kegiatan-kegiatan yang ada diantaranya melatih siswa menjadi imam sholat, hafal juz 30, dapat mempraktekkan ibadah-ibadah wajib dan sunnah dengan baik. Harapannya alumni MI Nurussalam selain berprestasi dalam hal akademik mereka juga mampu memiliki jiwa dan karakter Madrasah yakni karakter siswa yang religius/beragama serta memiliki mental yang kuat.

Dalam penanaman nilai-nilai karakter religius untuk kelas 1 sampai dengan 6, MI Nurussalam memperkenalkan dan menanamkan pada diri para siswa untuk cinta bahasa Arab karena bahasa Arab merupakan salah satu kunci untuk membuka wawasan tentang Islam serta sebagai bahasa Al-Qur'an . Selain pengajaran teori Bahasa Arab dalam kelas, MI Nurussalam menerapkan komunikasi dasar dalam Bahasa Arab secara langsung, para siswa dikenalkan dengan tatanan kalimat yang aplikatif seperti dalam perizinan ke kamar mandi, meminta kapur ke kantor, izin untuk minum, dll. Guru memberikan contoh dengan berkomunikasi bahasa Arab yang mudah ditiru dan dipraktekkan oleh siswa sehari-hari. Selain itu memperkenalkan bahasa arab dasar, MI Nurussalam juga mengadakan pelatihan pidato dalam Bahasa Arab dan Bahasa Inggris setiap hari Kamis, penempelan kosakata Bahasa Arab dalam benda-benda di sekitar lingkungan madrasah, dan ulang kaji kosa kata Bahasa Arab sebagai salah satu syarat masuk kantin dan kelas.

Bidang Non-Akademik

Penanaman nilai-nilai religius di MI Nurussalam dalam bidang Non-Akademik, penulis melihat hal-hal menarik dan berbeda dengan sekolah lainnya. Penulis membagi pada bagian ini yakni 4 bagian, yaitu kegiatan rutin, kegiatan spontan, kegiatan keteladanan, dan pengkondisian lingkungan Madrasah. 
Kegiatan rutin menurut Kemendiknas (2010:15), merupakan kegiatan yang dilakukan siswa secara terus menerus dan konsisten dari waktu ke waktu. Dalam hal ini, MI Nurussalam memberikan program rutin harian kepada seluruh siswanya untuk melaksanakan sholat Dhuhur dan sholat sunnah Dhuha secara berjamaah, mengadakan lomba nuansa keislaman setiap tahunnya, seperti lomba Pidato Akbar, MTQ, dan Cerdas Cermat Islami. Pembiasaan rutin harian yang MI Nurussalam terapkan diantaranya adalah berdoa sebelum masuk kelas, sebelum belajar, dan setelah belajar, dengan adanya kegiatankegiatan rutin tersebut maka siswa MI terbiasa dengan rutinitas religius sehingga siswa akan mudah menerima serta mengimplementasikan nilai-nilai karakter religius baik di madrasah maupun di luar madrasah.

Kegiatan Spontan adalah kegiatan yang dilakukan pada saat itu juga. Biasanya guru menasehati saat itu juga jika ada hal-hal negatif yang dilakukan oleh siswanya. Dan guru juga mengapresiasi siswanya jika saat itu melihat siswanya yang melakukan hal-hal positif. Dengan harapan siswa dapat mengingat bahwa hal negatif tidak perlu diulangi lagi, dan hal positif perlu dilakukan secara terus-menerus. Ada hal menarik di MI Nurussalam, jika ada azan berkumandang semua siswa diminta mendengarkan dan menjawab dengan seksama, jika ada siswa yang tidak mendengarkan dan tidak menjawab azan, maka saat itu juga para guru menasehati dan menegurnya.

Setiap hari semua guru MI Nurussalam mendapat jadwal untuk menjaga pelaksanaan dan pengawasan sholat Dhuha dan Dhuhur berjamaah di Masjid. Dalam hal ini guru yang bertugas melakukan pengawasan dan perbaikan tata cara wudhu sebelum sholat dhuha dan dzuhur. Selain pengawasan whudu, guru juga mengawasi etika setiap siswa masuk masjid. Ketika ada siswa yang tidak membaca doa masuk masjid dan barisan dalam sholat berjamaah kurang rapi, saat itu juga guru menegurnya. Guru juga selalu mengapresiasi siswa jika siswa melakukan hal-hal yang positif, semisal memberikan kata "pintar" kepada siswa yang sudah rapi barisannya dalam sholat, siswa yang membuang sampah di tempat sampah, dan hal positif lainnya.

Kegiatan Keteladanan dapat dilakukan oleh semua warga madrasah yang dapat dijadikan figur para siswa. Keteladanan adalah perilaku dan sikap guru dan tenaga kependidikan yang lain dalam memberikan contoh terhadap tindakan-tindakan yang baik sehingga dapat menjadi panutan para siswa, (Novan Ardi Wiyani, 2013:105). Dalam hal ini menurut data penulis yang telah didapatkan di lapangan, seluruh guru MI Nurussalam sudah dapat menjadi figur bagi semua siswa yang ada. Dengan sikap yang disiplin berpaikaian muslim/muslimah, ikut melaksanakan sholat Dhuha dan Dhuhur berjamaah, membimbing dalam menjwab dan mendengarkan saat azan berkumandang, adab makan dan minum sambil duduk serta diawali dan diakhiri dengan doa dan kegiatan positif lainnya.

Poin terkahir dalam hal non-akademik untuk menginternalisasikan nilai-nilai karakter religius kepada siswa adalah pengkondisian. Madrasah harus mendukung sepenuhnya keterlaksanaan pendidikan karakter dan budaya religius. Untuk dapat mencapai tujuan itu maka madrasah perlu untuk mengkondisikan lingkungan madrasah sedemikian rupa agar para siswa dan seluruh warga madrasah dapat dengan mudah untuk menerima dan melaksanakan nilai-nilai karakter religius di kehidupan sehari-hari. Pengkondisian yang MI Nurussalam lakukan untuk menanamkan nilai-nilai religius pada siswa adalah, MI Nurussalam membuat sejumlah aturan/disiplin seperti buang sampah pada tempatnya, membuat kantin kejujuran (melatih siswa membayar sesuai dengan apa yang dibelinya). 
Kantin kejujuran di MI Nurussalam, diimbangi dengan sistem pengawasan ketat dari guru, setiap waktu istirahat beberapa guru bertugas untuk mengawasi beberapa sudut kantin. Adanya slogan-slogan atau kata-kata mutiara Islami yang ditempel di kelas dan di depan kelas. Kondisi madrasah yang mendukung menjadikan proses penanaman atau penginternalisasian nilai-nilai karakter religius siswa di Madrasah lebih mudah.

\section{KESIMPULAN}

\section{Kesimpulan}

Strategi internalisasi nilai-nilai karakter religius di MI Nurussalam Mantingan yakni dengan pengembangan kurikulum pada mata pelajaran keislaman khusus di setiap tingkatan kelas. Kelas 1 dan 2 mewajibkan siswa mengikuti mata pelajaran AlQur'an/Iqra', Hafalan Doa dan Surat Pendek. Untuk kelas 3-6 mata pelajaran khususnya adalah Mahfudzat dan imla'. Pada evaluasi pembelajaran kelas 3 sampai dengan kelas 6, MI Nurussalam selalu menggunakan teknik evaluasi Tulis dan Lisan. Untuk evaluasi pembelajaran secara lisan, MI Nurussalam menamakan Ujian Lisan Ibadah Qouliyah dan Ibadah Amaliyah. Terkhusus kelas 6 yang akan menghadapi Ujian Nasional (UN) atau Ujian Akhir Madrasah Berstandar Nasional (UAMBN) wajib mengikuti karantina selama kurang lebih 2-3 bulan untuk menumbuhkan lebih dalam lagi nilai-nilai karakter religius di samping persiapan UN dan UAMBN. MI Nurussalam menerapkan komunikasi dasar dalam Bahasa Arab secara langsung untuk kelas 1 sampai dengan 6, para siswa dikenalkan dengan tatanan kalimat yang aplikatif seperti dalam perizinan ke kamar mandi, meminta kapur ke kantor, izin untuk minum, dll. Dalam bidang non-akademik, MI Nurussalam menginternalisasikan nilai-nilai karakter religius ke dalam kegiatan-kegiatan Madrasah baik rutin, kegiatan spontan, kegiatan keteladanan, dan pengkondisian lingkungan Madrasah.

\section{Saran}

Kegiatan akademik berbasis keislaman/religius yang ada di MI Nurussalam perlu terus ditingkatkan dan dikembangkan menyesuaikan perkembangan siswa dan lingkungan serta dapat pula dikembangkan dalam media pembelajaran yang menarik agar siswa lebih tertarik. Dalam bidang non-akademik, MI Nurussalam dapat lebih menambahkan lagi kegiatan-kegiatan yang lebih khusus dan memiliki karakteristik tersendiri yang dapat memberikan ciri khusus MI Nurussalam Mantingan dengan Madrasah yang lain. Bagi Madrasah yang belum memiliki program atau kegiatan dalam menginternalisasikan nilainilai karakter religius, maka dapat pula MI Nurussalam Mantingan menjadi contoh dalam penerapan implementasinya.

\section{REFERENSI}

Hasbullah, 2010. Otonomi Pendidikan: Kebijakan Otonomi Daerah dan Implikasinya terhadap Penyelenggaraan Pendidikan. Jakarta: PT Raja Grafindo Persada.

Waluyo, Bagja, 2007. Sosiologi: Menyelami Fenomena Sosial di Masyarakat. Bandung: PT. Setia Purna Inves.

Mulyana, Rahmat, 2004. Mengartikulasi Pendidikan Nilai, Cet. I, Bandung: Alfabeta.

Thoha, Chabib, 1996. Kapita Selekta Pendidikan Islam. Yogyakarta. 
Miles,M.B, Huberman,A.M, dan Saldana,J. 2014. Qualitative Data Analysis, A Methods Sourcebook, Edition 3. USA: Sage Publications. Terjemahan Tjetjep Rohindi Rohidi, UI-Press

Kemendiknas. 2010. Panduan Pendidikan Karakter di Sekolah Dasar. Jakarta : Direktorat Jenderal Manajemen Pendidikan.

Ardi, Novan Wiyani. 2013. Manajemen Kelas. Yogjakarta : Ar-Ruzz Media. 